\title{
Global Design and Optimization of a Permanent Magnet Synchronous Machine Used for Light Electric Vehicle
}

\author{
Daniel Fodorean \\ Technical University of Cluj-Napoca, Electrical Engineering Department \\ Romania
}

\section{Introduction}

One of the most common problems of modern society, these days, particularly for industrialized countries, is the pollution (Fuhs, 2009; Ehsani et al., 2005; Vogel, 2009; Ceraolo et al., 2006; Chenh-Hu \& Ming-Yang, 2007; Naidu et al., 2005). According to several studies, the largest share of pollution from urban areas comes from vehicle emissions and because of this explosive growth of the number of cars. The pollution effect is more and more obvious, especially in large cities. Consequently, finding a solution to reduce (or eliminate) the pollution is a vital need. If in public transports (trains, buses and trams) were found nonpolluted solutions (electrical ones), for the individual transport the present solutions can not yet meet the current need in autonomy. Even though historically the electric vehicle precedes the thermal engine, the power/fuel-consumption ratio and the reduced time to refill the tank has made the car powered by diesel or gasoline the ideal candidate for private transport. Although lately there were some rumors regarding the depletion of fossil resources, according to recent studies, America's oil availability is assured for the next 500 years (Fuhs, 2009; Ehsani et al., 2005). So, the need of breathing clean air remains the main argument for using electric vehicles (EV). However, all over the world, one of the current research topics concerns the use of renewable energy sources and EVs.

With regard to automobiles, there have been made several attempts to establish a maximum acceptable level of pollution. Thus, several car manufacturers have prepared a declaration of Partnership for a New Generation of Vehicles (PNGV), also called SUPERCAR. This concept provides, for a certain power, the expected performance of a thermal or hybrid car. Virtually, every car manufacturer proposes its own version of electric or hybrid car, at SUPERCAR standard, see Table 1 (Fuhs, 2009).

Of course, at concept level, the investment is not a criterion for the construction of EVs, as in the case of series manufacturing (where profits are severely quantified). For example, nowadays the price of $1 \mathrm{~kW}$ of power provided by fuel cell (FC) is around 4,500 $€$; thus, a FC of $100 \mathrm{~kW}$ would cost $450,000 €$ (those costs are practically prohibitive, for series manufacturing). By consulting Table 1, it can be noticed the interest of all car manufacturers to get a reduced pollution, with highest autonomy. Nowadays, the hybrid vehicles can be seen on streets. Although the cost of a hybrid car is not much higher than for the classical engine (about 15$25 \%$ higher), however, the first one requires supplementary maintenance costs which cannot be quantified in this moment. 


\begin{tabular}{|c|c|c|}
\hline Concept Cars & Technical Data & Performances \\
\hline $\begin{array}{l}\text { AUDI metroproject } \\
\text { quattro }\end{array}$ & $\begin{array}{l}\text { turbocharged four-cylinder engine and an } \\
\text { electric machine of } 30 \mathrm{~kW} \text {; lithium-ion battery }\end{array}$ & $\begin{array}{l}\text { maximum range on electric-only of } \\
100 \mathrm{~km} ; 0-100 \mathrm{~km} / \mathrm{h} \text { in } 7.8 \mathrm{~s} ; \text { maximum } \\
\text { speed } 200 \mathrm{~km} / \mathrm{h}\end{array}$ \\
\hline BMW x5 hybrid SUV & $\begin{array}{l}\text { for } 1000 \mathrm{rpm} \text {, there is a V-8 engine providing } \\
1000 \mathrm{Nm} \text {; the electric motor gives } 660 \mathrm{Nm}\end{array}$ & $\begin{array}{l}\text { fuel economy is improved by an } \\
\text { estimated } 20 \% \text {. }\end{array}$ \\
\hline $\begin{array}{l}\text { CHRYSLER eco } \\
\text { voyager FCV }\end{array}$ & $\begin{array}{l}\text { propulsion of } 200 \mathrm{~kW} \text {; hydrogen is feed to a } \\
\text { PEM fuel cell (FC) }\end{array}$ & $\begin{array}{l}\text { range of } 482 \mathrm{~km} \text { and a } 0-60 \mathrm{~km} / \mathrm{h} \text { in } \\
\text { less than } 8 \mathrm{~s} \text {. }\end{array}$ \\
\hline $\begin{array}{l}\text { CITROËN c-cactus } \\
\text { hybrid }\end{array}$ & $\begin{array}{l}\text { diesel engine provides } 52 \mathrm{~kW} \text { and the electric } \\
\text { motor gives } 22 \mathrm{~kW}\end{array}$ & $\begin{array}{l}\text { fuel consumption is } 2.0 \mathrm{~L} / 100 \mathrm{~km} \text {; } \\
\text { maximum speed is } 150 \mathrm{~km} / \mathrm{h}\end{array}$ \\
\hline FORD hySeries EDGE & $\begin{array}{l}\text { Li-ion battery has maximum power of } \\
130 \mathrm{~kW} \text {, and the FC provides } 35 \mathrm{~kW}\end{array}$ & $\begin{array}{l}\text { range of } 363 \mathrm{~km} \text { (limited by the amount } \\
\text { of hydrogen for the FC) }\end{array}$ \\
\hline HONDA FCX & $\begin{array}{l}\text { electric vehicle with } 80 \mathrm{~kW} \text { propulsion engine, } \\
\text { combining ultracapacitors (UC) and PEM FC }\end{array}$ & $\begin{array}{l}55 \% \text { for overall efficiency, driving } \\
\text { range of } 430 \mathrm{~km}\end{array}$ \\
\hline $\begin{array}{l}\text { HYUNDAI I-blue } \\
\text { FCV }\end{array}$ & $\begin{array}{l}\text { FC stack produces } 100 \mathrm{~kW} \text {; there is a } 100 \mathrm{~kW} \\
\text { electric machine (front wheels) and } 20 \mathrm{~kW} \\
\text { motor for each rear wheel }\end{array}$ & estimated range is $600 \mathrm{~km}$ \\
\hline $\begin{array}{l}\text { JEEP renegade diesel- } \\
\text { electric }\end{array}$ & $\begin{array}{l}1.5 \mathrm{~L} \text { diesel engine provides } 86 \mathrm{~kW} \text { and is } \\
\text { teamed with } 4 \text { electric motors }(4 \mathrm{WD}) \text { of } \\
85 \mathrm{~kW} \text { combined power }\end{array}$ & $\begin{array}{l}\text { the diesel provides range extension up } \\
\text { to } 645 \mathrm{~km} \text { beyond the } 64 \mathrm{~km} \text { electric- } \\
\text { only range (diesel fuel tank holds } 38 \mathrm{~L} \text { ) }\end{array}$ \\
\hline KIA FCV & $\begin{array}{l}\text { a } 100 \mathrm{~kW} \text { FC suppliss a } 100 \mathrm{~kW} \text { front wheel } \\
\text { electric motor, while the motor driving the } \\
\text { rear wheels is } 20 \mathrm{~kW}\end{array}$ & range is stated to be $610 \mathrm{~km}$ \\
\hline $\begin{array}{l}\text { MERCEDES BENZ s- } \\
\text { class direct hybrid }\end{array}$ & $\begin{array}{l}3.5 \mathrm{~L}(\mathrm{~V}-6) \text { gasoline engine with } \\
\text { motor/generator combined power of } 225 \mathrm{~kW} \\
\text { and combined torque of } 388 \mathrm{Nm}\end{array}$ & $\begin{array}{l}\text { acceleration time from } 0-100 \mathrm{~km} / \mathrm{h} \text { in } \\
7.5 \mathrm{~s}\end{array}$ \\
\hline MITSUBISHI pure EV & Li-ion battery and wheel-in-motors of $20 \mathrm{~kW}$ & $\begin{array}{l}150 \mathrm{~kg} \text { Li-ion battery give a range of } \\
150 \mathrm{~km}(2010 \text { prospective range of } \\
250 \mathrm{~km}\end{array}$ \\
\hline OPEL flextreme & $\begin{array}{l}\text { a series hybrid configuration (with diesel } \\
\text { engine) with Li-ion battery; the electric motor } \\
\text { has peak power of } 120 \mathrm{~kW}\end{array}$ & $\begin{array}{l}\text { fuel consumption of } 1.5 \mathrm{~L} / 100 \mathrm{~km} \text {; } \\
\text { electric only mode has range of } 55 \mathrm{~km}\end{array}$ \\
\hline PEUGEOT 307 hybrid & it is diesel/electric hybrid automobile & $\begin{array}{l}\text { the estimated fuel economy is } 82 \mathrm{mpg} ; \\
\text { this is a hybrid that matches the PNGV } \\
\text { goals }\end{array}$ \\
\hline SUBARU G4E & five passengers EV, using Li-ion batteries & $\begin{array}{l}\text { driving range is } 200 \mathrm{~km} \text {; the battery can } \\
\text { be fully charged at home in } 8 \mathrm{~h} \text { (an } 80 \% \\
\text { charge is possible in } 15 \mathrm{~min} \text { ) }\end{array}$ \\
\hline $\begin{array}{l}\text { TOYOTA } 1 / \text { X plug-in } \\
\text { hybrid }\end{array}$ & $\begin{array}{l}\text { thermal engine } 0.5 \mathrm{~L} \text {, with a huge reduction } \\
\text { of mass to } 420 \mathrm{~kg} \text { (use of carbon fiber } \\
\text { composites, although expensive) }\end{array}$ & $\begin{array}{l}\text { low mass also means low engine power } \\
\text { and fuel consumption }\end{array}$ \\
\hline $\begin{array}{l}\text { VOLKSWAGEN Blue } \\
\text { FC }\end{array}$ & $\begin{array}{l}\text { a } 12 \mathrm{~kW} \text { FC mounted in the front charges } \\
12 \mathrm{Li}-\text { ion batteries at the rear; The } 40 \mathrm{~kW} \\
\text { motor is located at the rear }\end{array}$ & $\begin{array}{l}\text { the electric-only range is } 108 \mathrm{~km} \text {; top } \\
\text { speed is } 125 \mathrm{~km} / \mathrm{h} \text {, and the acceleration } \\
\text { time from } 0-100 \mathrm{~km} / \mathrm{h} \text { is } 13.7 \mathrm{~s}\end{array}$ \\
\hline VOLVO recharge & $\begin{array}{l}\text { series hybrid with lithium polymer batteries; } \\
\text { the engine is of } 4 \text {-cylinder type with1.6 L; it } \\
\text { has } 4 \text { electric wheels motors (AWD) }\end{array}$ & $\begin{array}{l}\text { electric-only range is } 100 \mathrm{~km} \text {; for a } \\
150 \mathrm{~km} \text { trip, the fuel economy is } \\
1.4 \mathrm{~L} / 100 \mathrm{~km}\end{array}$ \\
\hline
\end{tabular}

Table 1. Several types of hybrid vehicle concepts.

Some predictions on the EV's were considered by (Fuhs, 2009). In the nearest future the thermal automobiles number will decrease, while the hybrid ones are taking their place. By 2037 the fully electric vehicle (called kit car) will replace the engine and then, after a fuzzy period all vehicles will be powered based on clean energy sources, when a new philosophy of building and using the cars will be put in place.

So, one of the challenges of individual transport refers to finding clean solutions, with enhanced autonomy (Ceraolo et al., 2006; Chenh-Hu \& Ming-Yang, 2007; Naidu et al., 2005). 
This is the motivation of this research work. For that, an electric scooter will be studied from the motorization, supplying and control point of view. The global steps of the design process will be presented here. Firstly, the considered load and expected mechanical performances will be introduced. The electromagnetic design of the electrical motor, capable to fulfill the mechanical performances, will be presented too. The obtained analytical performances should be validated; for that, the finite element method will be used. Also, the machine optimization will fulfill the global designing process of the electrical machine.

\section{Design of studied electrical machine}

The research study presented here concerns the design of a three phase permanent magnet synchronous machine (PMSM) used for the propulsion of an electric scooter. It is widely recognized that the common solution, the dc motor, has usually poor performances against ac motor. However, for low small power electrical machines, this advantage is not always obvious. Also, a special attention should be paid for the efficiency and power factor of ac machines. This will be analyzed here. The validation of the obtained results will be made based on finite element method (FEM) analysis. The goal is to increase the autonomy of the light electric vehicle, based on a PMSM, with a proper control, and after the optimization of the designed machine.

The analytical approach, employed here, can be used for any type of electric vehicle. First of all, for a given maximum load, it will be established the necessary power needed for the propulsion of the vehicle. Secondly, the main steps in the design process of the studied machine will be given. Next, the energetic performances and electro-mechanical characteristics will be presented. The validation of the analytical obtained results is made based on finite element method (FEM). By means of numerical computation, it will be demonstrated that a unity power factor control is possible when using ac machines, by employing a field oriented control strategy. The optimization of the studied machine will be realized based on gradient type algorithm and the obtained results will show the benefits of using a PMSM for the propulsion of the light electric vehicle.

\subsection{The needed mechanical performances}

The maximum speed and weight of the vehicle are $12 \mathrm{~km} / \mathrm{h}$ and $158 \mathrm{~kg}$, respectively. The considered vehicle has 4 tires of 11 inches in diameter. The vehicle dimensions are: $1290 \mathrm{~mm}$ in length, $580 \mathrm{~mm}$ in width and $1150 \mathrm{~mm}$ in height. The vehicle will be supplied from a battery of $24 \mathrm{Vcc}$.

First of all, it is needed to compute the output power of the electric motor which is capable to run the vehicle. Since the mechanical power is the product between the mechanical torque and angular speed, it is possible to establish the speed of the vehicle at the wheel:

$$
\mathrm{n}_{\mathrm{t}}=\mathrm{v} \cdot 60 /\left(\pi \cdot \mathrm{D}_{\mathrm{t}}\right)
$$

where $n_{t}$ is the velocity measured at the vehicle's wheels (measured in min- 1 ), $v$ is the vehicle speed (in $m / s$ ), $\mathbf{D}_{\mathbf{t}}$ is the outer diameter of the wheel (the tire height included, in $m$ ). The resulted velocity is $\mathrm{n}_{\mathrm{t}}=244.4 \mathrm{~min}^{-1}$. From mechanical and controllability considerations, it is desirable to have an electric motor operating at higher speed, so it is considered a gear ratio of 6.1 to 1 . Thus the electric motor rated speed is imposed at $1500 \mathrm{~min}^{-1}$.

Next, the rated torque has to be established. Since the motor torque is proportional to the wheel radius and the force acting on it, one should determine the force involved by the 
vehicle's weight and rolling conditions. The electric motor has to be capable to produce a mechanical force to balance all other forces which interfere in vehicle's rolling. Thus, the motor force is:

$$
\mathrm{F}_{\mathrm{m}}=\mathrm{F}_{\mathrm{acc}}+\mathrm{F}_{\mathrm{h}}+\mathrm{F}_{\mathrm{d}}+\mathrm{F}_{\mathrm{w}}+\mathrm{F}_{\mathrm{r}}
$$

where $F_{\text {acc }}$ is the acceleration force, $F_{h}$ is the climbing force, $F_{d}$ is the aerodynamic drag force, $F_{W}$ is a resistive force due to the wind, and $F_{r}$ is the rolling force.

Since the vehicle studied here is not for racing, and will be controlled to start smoothly, no acceleration constraints are imposed.

When the vehicle goes hill climbing, based on angle of incline $\theta$, the climbing force is:

$$
\mathrm{F}_{\mathrm{h}}=\mathrm{M}_{\mathrm{tot}} \cdot \mathrm{g} \cdot \sin (\theta)
$$

where $\mathbf{M}_{\text {tot, }}$ is the total mass of the vehicle (in $\mathrm{kg}$ ), $\mathrm{g}$ is the gravitational constant $\left(9.8 \mathrm{~m} / \mathrm{s}^{2}\right)$.

Usually, the degree of incline is given in percentage. For this special electric scooter it is considered a maximum $8 \%$ degree of incline. $1 \%$ degree of incline represents the ratio of 1 meter of rise, on a distance of 100 meters. Thus, $1 \%=\operatorname{atan}(0.01)=0^{\circ} 34^{\prime}$ (zero degrees and 34 minutes). For an incline of $8 \%$, the angle is $4^{\circ} 34^{\prime}$ (or 4.57 degrees).

The drag force takes into account the aerodynamics of the vehicle. This force is proportional with the square of the speed, the frontal area of the vehicle $\left(\mathrm{A}_{\mathrm{fr}}\right.$, here $\left.0.668 \mathrm{~m}^{2}\right)$ and the aerodynamic coefficient, $\mathrm{k}_{\mathrm{d}}$ (empirically determined, for each specific vehicle (Vogel, 2009)):

$$
\mathrm{F}_{\mathrm{d}}=\mathrm{A}_{\mathrm{fr}} \cdot \mathrm{v}^{2} \cdot \mathrm{g} \cdot \mathrm{k}_{\mathrm{d}}
$$

The resistant force due to wind, cannot be precisely computed. It depends on various conditions, like (for common automobiles) the fact that windows are entirely or partially open etc... Also, the wind will never blow at constant speed. However, an expression, determined empirically, which will take into account the speed of wind, $\mathrm{v}_{\mathrm{w}}$, can be written as (Vogel, 2009):

$$
\mathrm{F}_{\mathrm{w}}=\left(\left(0.98 \cdot\left(\mathrm{v}_{\mathrm{w}} / \mathrm{v}\right)^{2}+0.63 \cdot\left(\mathrm{v}_{\mathrm{w}} / \mathrm{v}\right)\right) \cdot \mathrm{k}_{\mathrm{rw}}-0.4 \cdot\left(\mathrm{v}_{\mathrm{w}} / \mathrm{v}\right)\right) \cdot \mathrm{F}_{\mathrm{d}}
$$

where $\mathrm{k}_{\mathrm{rw}}$ is the wind relative coefficient, depending on the vehicle's aerodynamics, (here is 1.6).

The resistant force due to rolling depends on the hardness of the road's surface, being proportional with the weight of the vehicle and the angle of incline:

$$
\mathrm{F}_{\mathrm{r}}=\mathrm{k}_{\mathrm{r}} \cdot \mathrm{M}_{\mathrm{tot}} \cdot \mathrm{g} \cdot \cos (\theta)
$$

(here, the road surface coefficient, $k_{r}$, is 0.011 ).

A more precise computation of the rolling resistant force could take into account also the shape and the width of the tires, but these elements are not critical at low speeds, like in this case.

After the computation of the resistant forces, it can be determined the needed torque at the wheel, see Table 2, and finally the rated torque of the electrical machine.

For this specific value of the torque at the wheel, a power of $505.1 \mathrm{~W}$ is required. Nevertheless, for small power electrical traction systems, the efficiency is quite poor. Here, the efficiency is estimated at $75 \%$. This means that the output power of the electrical motor, capable to operate in the specified road/mechanical conditions, it has to be at least of $673.5 \mathrm{~W}$. Thus, rounding the power, it is obtained a $700 \mathrm{~W}$ electrical machine. 
It is now possible to identify the mechanical characteristics of the electrical machines. Two traction motors are considered, with a gear ratio of 6.1 to 1 . Thus, the rated mechanical characteristics for one motor are: $350 \mathrm{~W}, 1500 \mathrm{rpm}, 2.2 \mathrm{~N} \cdot \mathrm{m}$.

\begin{tabular}{|l|l|l|l|l|l|}
\hline $\mathbf{F}_{\mathbf{h}}(\mathbf{N})$ & $\mathbf{F}_{\mathbf{d}} \mathbf{( N )}$ & $\mathbf{F}_{\mathbf{w}}(\mathbf{N})$ & $\mathbf{F}_{\mathbf{r}}(\mathbf{N})$ & $\mathbf{F}_{\mathbf{m}}(\mathbf{N})$ & $\begin{array}{l}\text { torque at the } \\
\text { wheel }(\mathbf{N} \cdot \mathbf{m})\end{array}$ \\
\hline 123.5 & 0.026 & 0.667 & 16.98 & 141.2 & 19.73 \\
\hline
\end{tabular}

Table 2. Computed resistant forces and the torque at the wheel.

\subsection{Electromagnetic design of the PMSM}

The permanent magnet synchronous machine (PMSM) has to provide a maximum power density. For that, good quality materials should be used. The permanent magnet (PM) material is of Nd-Fe-B type, with $1.25 \mathrm{~T}$ remanent flux density. The steel used for the construction of PMSM is M530-50A. The material characteristics are presented in Fig. 1.
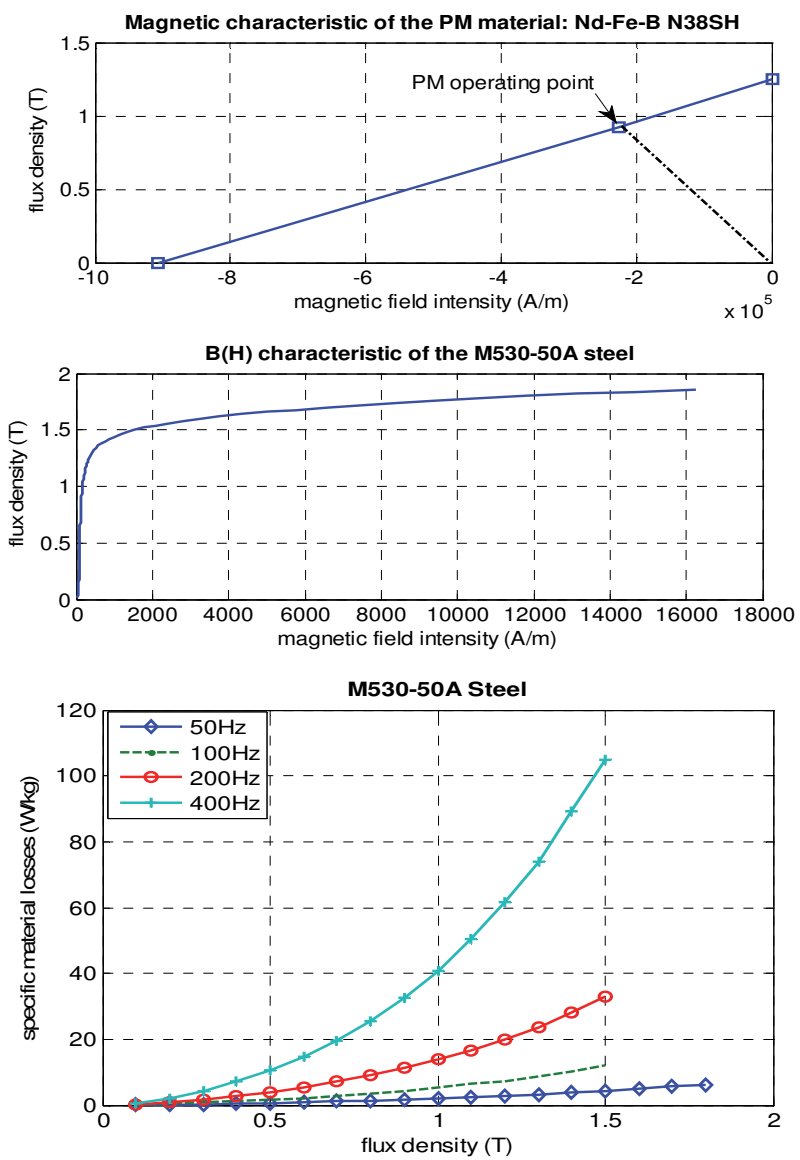

Fig. 1. The PM and steel characteristics used as the active part's materials of the PMSM. 
For the PM, the N38SH material was use. This rear earth magnet can be irreversible demagnetized starting from $120^{\circ} \mathrm{C}$. The $1.25 \mathrm{~T}$ remanent flux density $\left(\right.$ at $20^{\circ} \mathrm{C}$ ) is however affected with the temperature increase. In order to compute the real value of the $\mathrm{PM}^{\prime} \mathrm{s}$ remanent flux density, for a temperature derivative coefficient of $0.1 \%$ and for an increase in temperature of $110 \mathrm{~K}$, the rated operating point of the $\mathrm{PM}$ is $1.11 \mathrm{~T}$ (based on the mathematical expression $\left.\mathrm{X}_{20^{\circ} \mathrm{C}+\Delta \mathrm{T}}=\mathrm{X}_{20^{\circ} \mathrm{C}} \cdot\left(1-\alpha_{\mathrm{x}} \cdot \Delta \mathrm{T}\right)\right)$.

In order to obtain a smooth torque wave, a fractioned winding type is used. Thus, the PMSM has 8 pair of poles and 18 slots. The geometry of the PMSM, the winding configuration and the obtained phase resultant vectors are shown in Fig. 2.

The design approach is based on the scientific literature presented in (Pyrhonen et al., 2008; Fitzgerald et al., 2003; Huang et al., 1998). The output power (measured in $W$ ) of an electric machine, when the leakage reactance is neglected, is proportional with the number of phases of the machine, $n_{p h}$, the phase current, $i(t)$, and the inducted electromotive force $(\mathrm{emf}), \mathrm{e}(\mathrm{t})$ :

$$
\mathrm{P}_{\text {out }}=\eta \cdot \frac{\mathrm{n}_{\mathrm{ph}}}{\mathrm{T}} \cdot \int_{0}^{\mathrm{T}} \mathrm{e}(\mathrm{t}) \cdot \mathrm{i}(\mathrm{t}) \mathrm{dt}=\eta \cdot \mathrm{n}_{\mathrm{ph}} \cdot \mathrm{k}_{\mathrm{p}} \cdot \mathrm{E}_{\max } \cdot \mathrm{I}_{\max }
$$

where $\mathrm{T}$ is the period of one cycle of emf, $\mathrm{E}_{\max }$, and $\mathrm{I}_{\max }$ represent the peak values of the emf and phase current, $\mathrm{k}_{\mathrm{p}}$ is the power coefficient, and $\eta$ is the estimated efficiency.

The peak value of the emf is expressed by introducing the electromotive force coefficient, $\mathrm{k}_{\mathrm{E}}$ :

$$
E_{\text {max }}=k_{E} \cdot N_{t} \cdot B_{\text {gap }} \cdot D_{\text {gap }} \cdot L_{m} \cdot f_{s} / p
$$

where $\mathrm{N}_{t}$ is the number of turns per phase, $B_{\text {gap }}$ and $D_{\text {gap }}$ are the air-gap flux density and diameter, $\mathrm{L}_{\mathrm{m}}$ is the length of the machine, $\mathrm{f}_{\mathrm{s}}$ is the supplying frequency and $\mathrm{p}$ is the number of pole pairs.

By introducing a geometric coefficient, $\mathrm{k}_{\mathrm{L}}=\mathrm{L}_{\mathrm{m}} / \mathrm{D}_{\text {gap }}$, and a current coefficient (related to its wave form) $\mathrm{k}_{\mathrm{i}}=\mathrm{I}_{\mathrm{max}} / \mathrm{I}_{\mathrm{rms}}$, and defining the phase load ampere-turns,

$$
A_{\text {th }}=2 / \pi \cdot N_{t} \cdot I_{\text {rms }} / D_{\text {gap }}
$$

it is possible to define the air-gap diameter of the machine:

$$
D_{\text {gap }}=\sqrt[3]{\frac{2 \cdot p \cdot P_{\text {out }}}{\Pi \cdot n_{p h} \cdot A_{t} \cdot k_{e} \cdot k_{i} \cdot k_{p} \cdot k_{L} \cdot \eta \cdot B_{\text {gap }} \cdot f_{s}}}
$$

Based on the type of the current wave form, it is possible to define the current and power coefficients (Huang et al., 1998). Thus, for sinusoidal current wave form, $\mathrm{k}_{\mathrm{i}}=\sqrt{2}, \mathrm{k}_{\mathrm{p}}=0.5$, for rectangular current wave $\mathrm{k}_{\mathrm{i}}=1, \mathrm{k}_{\mathrm{p}}=1$ and for trapezoidal current wave $\mathrm{k}_{\mathrm{i}}=$ $1.134, \mathrm{k}_{\mathrm{p}}=0.777$.

All the other geometric parameters will be computed based on this air-gap diameter. The designer has to choose only the PMs shape and stator slots.

The air-gap flux density is computed based on the next formula:

$$
\mathrm{B}_{\text {gap }}=\frac{\mathrm{h}_{\mathrm{m}} \cdot \mathrm{B}_{\mathrm{rm}}}{\frac{\mathrm{D}_{\text {gap }}}{2} \cdot\left(\ln \left(\frac{\mathrm{R}_{\mathrm{si}}-\mathrm{gap}}{\mathrm{R}_{\mathrm{cr}}}\right)+\ln \left(\frac{\mathrm{R}_{\mathrm{si}}}{\mathrm{R}_{\mathrm{si}}-\text { gap }}\right)\right)}
$$


where, $\mathrm{h}_{\mathrm{m}}$ and $\mathrm{B}_{\mathrm{rm}}$ are the PM length on magnetization direction (in $m$ ) and the remanent flux-density (in tesla), respectively, $R_{\mathrm{si}}$ and $\mathrm{R}_{\mathrm{cr}}$ are inner stator radius and rotor core radius, respectively.

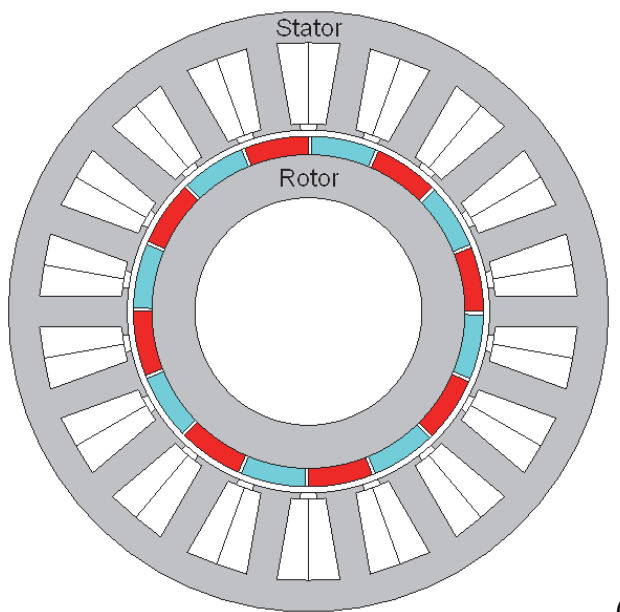

(a)

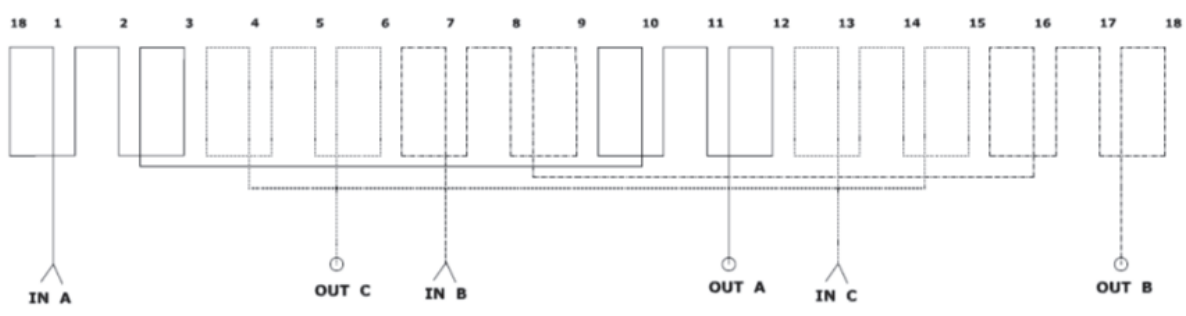

(b)

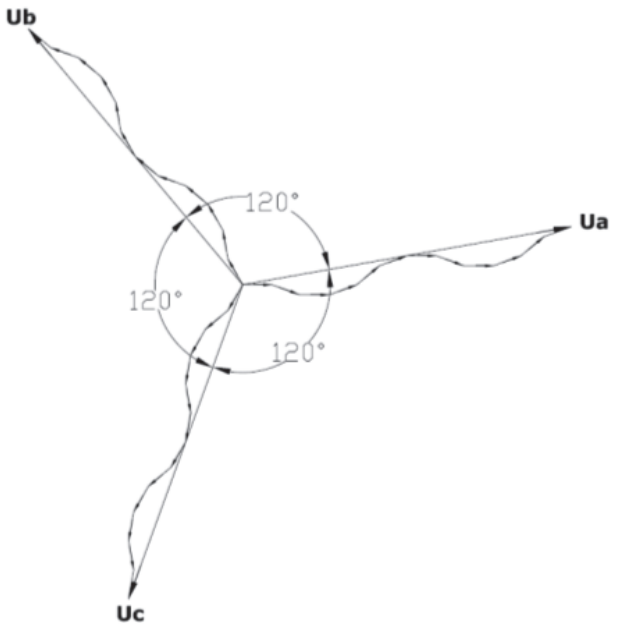

(c)

Fig. 2. The PMSM: (a) geometry; (b) fractioned type winding configuration; (c) the resultant voltage vectors. 
The saturation factor, $\mathrm{k}_{\mathrm{s}}$, has to be computed in order to take into account the non-linearity of the steel. $\mathrm{k}_{\mathrm{s}}$ depends on the equivalent magnetomotive force, $\mathrm{F}_{\mathrm{m}}$, in each active part of the machine and in the air-gap:

$$
\mathrm{k}_{\mathrm{s}}=\left(2 \cdot \mathrm{F}_{\mathrm{mt}}+\mathrm{F}_{\mathrm{my}}+\mathrm{F}_{\mathrm{mr}}+2 \cdot \mathrm{F}_{\mathrm{mg}}\right) /\left(2 \cdot \mathrm{F}_{\mathrm{mg}}\right)
$$

where ' $t$ ', ' $y$ ', ' $r$ ' and ' $g$ ' indices refer to the stator teeth and yoke, rotor core and air-gap, respectively. Each magnetomotive force is computed based on the magnetic field intensity $(\mathrm{H})$ and the length $(\mathrm{l})$ of the active part of the machine, on the flux direction:

$$
\mathrm{F}_{\mathrm{mx}}=\mathrm{H}_{\mathrm{x}} \cdot \mathrm{l}_{\mathrm{x}}
$$

Equation (13) is general and used for the computation of the magnetomotive force in each active part of the machine, while ' $x$ ' replaces ' $t$ ', ' $y$ ', ' $r$ ' and ' $g$ ' indices. The parameter $l_{x}$ can be easily expressed. Further on, the magnetic field intensity is computed. The $\mathrm{H}_{\mathrm{x}}$ value can be chosen from the supplier $\mathrm{B}(\mathrm{H})$ magnetic characteristic (for each computed value of the flux density).

Next, the electromagnetic parameters of the PMSM should be determined. The phase resistance depends on: copper resistivity, $\rho_{\mathrm{co}}$, length of series turns, $\mathrm{l}_{\mathrm{t}}$, and conductor cross section, $\mathrm{S}_{\mathrm{c}}$ :

$$
\mathrm{R}_{\mathrm{ph}}=\rho_{\mathrm{co}} \cdot \mathrm{l}_{\mathrm{t}} / \mathrm{S}_{\mathrm{c}}
$$

The $d-q$ axis reactances are computed based on magnetizing $\left(\mathrm{X}_{\mathrm{m}}\right)$ and leakage $\left(\mathrm{X}_{\sigma}\right)$ reactances:

$$
\mathrm{X}_{\mathrm{d}, \mathrm{q}}=\mathrm{X}_{\sigma}+\mathrm{X}_{\mathrm{m}_{-} \mathrm{d}, \mathrm{q}} \cdot \mathrm{k}_{\mathrm{a}_{-} \mathrm{d}, \mathrm{q}} / \mathrm{k}_{\mathrm{s}}
$$

where $d-q$ magnetizing reactances depend on the saliency coefficient, $\mathrm{k}_{a \_d} \mathrm{~d}$, (which equals unity for surface mounted PM machines: $X_{m_{-} d}=X_{m_{-} q}$ ):

$$
\begin{gathered}
\mathrm{X}_{\mathrm{m}_{-} \mathrm{d}, \mathrm{q}}=4 \cdot \mathrm{n}_{\mathrm{ph}} \cdot \mathrm{f}_{\mathrm{s}} \cdot \tau_{\mathrm{p}} \cdot \mathrm{L}_{\mathrm{m}} \cdot\left(\mathrm{N}_{\mathrm{t}} \cdot \mathrm{k}_{\mathrm{ws}}\right)^{2} \cdot \mu_{0} \cdot \mathrm{k}_{\mathrm{a}_{\mathrm{d}}, \mathrm{q}} /(\pi \cdot \mathrm{p} \cdot \mathrm{gap}) \\
\mathrm{X}_{\sigma}=4 \cdot \pi \cdot \mathrm{f}_{\mathrm{s}} \cdot\left(\mathrm{N}_{\mathrm{t}}\right)^{2} \cdot \mu_{0} \cdot \sum \Lambda_{\sigma} /(\mathrm{p} \cdot \mathrm{q})
\end{gathered}
$$

where $\tau_{\mathrm{p}}$ is the polar pitch, $\mathrm{k}_{\mathrm{ws}}$ is the winding factor, $\mathrm{q}$ is the number of slots per pole and per phase, and $\sum \Lambda_{\sigma}$ is the sum of leakage permeances. The saliency ratios (for saliency rotors) are:

$$
\begin{gathered}
\mathrm{k}_{\mathrm{a}_{-} \mathrm{d}}=\frac{\Pi \cdot \mathrm{a}_{\mathrm{mp}}+\sin \left(\Pi \cdot \mathrm{a}_{\mathrm{mp}}\right)}{4 \cdot \sin \left(\mathrm{a}_{\mathrm{mp}} \cdot \Pi / 2\right)} \\
\mathrm{k}_{\mathrm{a}_{-} \mathrm{q}}=\frac{\Pi \cdot \mathrm{a}_{\mathrm{mp}}-\sin \left(\Pi \cdot \mathrm{a}_{\mathrm{mp}}\right)+2 / 3 \cdot \cos \left(\mathrm{a}_{\mathrm{mp}} \cdot \Pi / 2\right)}{4 \cdot \sin \left(\mathrm{a}_{\mathrm{mp}} \cdot \Pi / 2\right)}
\end{gathered}
$$

where $a_{m p}$ is a coefficient representing the percentage of magnet covering the rotor pole.

For motor operation of PMSM (with magnetic anisotropy), we can use the typical load phasor diagram, in $d-q$ reference frame, Fig. 3 . From this phasor diagram one will get the $d-q$ axis reactances equations, function of phase voltage, $U_{\mathrm{ph}}$, phase electromotive force, $\mathrm{E}_{\mathrm{ph}}$ phase resistance, $R_{p h}$ d-q axis currents and internal angle, $\delta$ : 


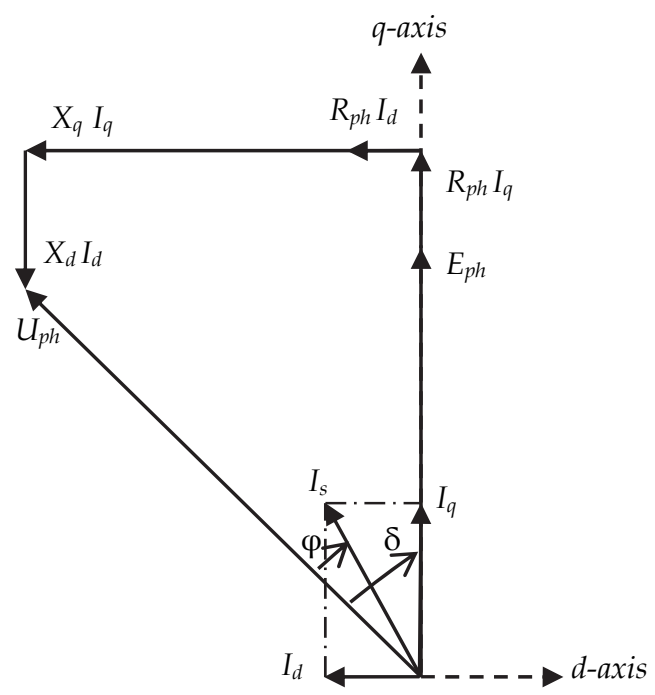

Fig. 3. Phasor diagram for PMSM in motor-load conditions.

$$
\begin{gathered}
\mathrm{X}_{\mathrm{d}}=\left(\mathrm{U}_{\mathrm{ph}} \cdot \cos (\delta)-\mathrm{E}-\mathrm{R}_{\mathrm{ph}} \cdot \mathrm{I}_{\mathrm{q}}\right) / \mathrm{I}_{\mathrm{d}} \\
\mathrm{X}_{\mathrm{q}}=\left(\mathrm{U}_{\mathrm{ph}} \cdot \sin (\delta)+\mathrm{R}_{\mathrm{ph}} \cdot \mathrm{I}_{\mathrm{d}}\right) / \mathrm{I}_{\mathrm{q}}
\end{gathered}
$$

Also, it is possible to compute the source current, $I_{s}=\sqrt{I_{d}^{2}+I_{q}^{2}}$, knowing that the direct and quadrature current are obtained by developing (19):

$$
\begin{array}{r}
I_{d}=\frac{U_{p h} \cdot\left(X_{q} \cdot \cos (\delta)-R_{p h} \cdot \sin (\delta)\right)-E_{p h} \cdot X_{q}}{R_{p h}^{2}+X_{d} \cdot X_{q}} \\
I_{q}=\frac{U_{p h} \cdot\left(X_{d} \cdot \cos (\delta)+R_{p h} \cdot \sin (\delta)\right)-E_{p h} \cdot R_{p h}}{R_{p h}^{2}+X_{d} \cdot X_{q}}
\end{array}
$$

The electromotive force is proportional with the frequency, the number of turns, the air-gap flux per pole and a demagnetization coefficient, $\mathrm{k}_{\mathrm{d}}$ (given by the PMs material supplier, usually between $0.8-0.9$ for rare earth PMs):

$$
E_{p h}=\sqrt{2} \cdot \pi \cdot f_{s} \cdot N_{t} \cdot k_{w s} \cdot \Psi_{g a p} \cdot k_{d}
$$

Next, the common electromechanical characteristics can be also computed, namely: the input power:

$$
P_{\text {in }}=n_{p h} \cdot U_{p h} \cdot\left(I_{q} \cdot \cos (\delta)-I_{d} \cdot \sin (\delta)\right)
$$

the output power (function of the sum of losses) and axis torque:

$$
P_{\text {out }}=P_{\text {in }}-\sum \text { Losses }
$$




$$
T_{m}=P_{\text {out }} / \Omega
$$

the energetic performances (power factor and efficiency, respectively):

$$
\begin{gathered}
\cos \varphi=P_{\text {in }} /\left(n_{p h} \cdot U_{p h} \cdot I_{S}\right) \\
\eta=P_{\text {in }} / P_{\text {out }}
\end{gathered}
$$

The sum of losses contains the copper (the product between the phase resistance and square current), iron, mechanical (neglected here) and supplementary (estimated to $0.5 \%$ of output power) losses.

After the designing process, the following results have been obtained, see Table 3 . The reader's attention is now oriented towards the energetic performances of the PMSM.

\begin{tabular}{|l|c|}
\hline \multicolumn{1}{|c|}{ Parameter } & PMSM \\
\hline Output power $(\mathrm{W})$ & 350 \\
\hline Rated speed (rpm) & 1500 \\
\hline Rated torque $(\mathrm{N} \cdot \mathrm{m})$ & 2.2 \\
\hline Battery voltage $(\mathrm{V})$ & 24 \\
\hline Number of phases $(-)$ & 3 \\
\hline Number of pole pairs $(-)$ & 8 \\
\hline Number of slots $(-)$ & 18 \\
\hline Outer diameter $(\mathrm{mm})$ & 98.7 \\
\hline Machine length $(\mathrm{mm})$ & 43.5 \\
\hline Airgap length $(\mathrm{mm})$ & 1 \\
\hline Airgap flux density $(\mathrm{T})$ & 0.83 \\
\hline Phase resistance $(\Omega)$ & 0.0424 \\
\hline$d$ axis inductance $(\mathrm{mH})$ & 0.30515 \\
\hline$q$ axis inductance $(\mathrm{mH})$ & 0.30515 \\
\hline Phase emf $(\mathrm{V})$ & 9.058 \\
\hline Rated current $(\mathrm{A})$ & 16.64 \\
\hline Losses $(\mathrm{W})$ & 71.4 \\
\hline Power factor $(\%)$ & 60.9 \\
\hline Efficiency $(\%)$ & 83.06 \\
\hline Active part costs $(€)$ & 27.15 \\
\hline Active part mass $(\mathrm{kg})$ & 2.69 \\
\hline Power/mass $(\mathrm{W} / \mathrm{kg})$ & 130.1 \\
\hline
\end{tabular}

Table 3. Comparison of obtained results for the designed PMSM.

\subsection{Drive modeling for controlling the PMSM}

The power factor for the PMSM is quite reduced (as it can be seen in Table 3). In order to increase the power factor, it is possible to use capacitor battery connected to stator winding. This solution is expensive and non-reliable. On the other hand, the current, and finally the power factor are depending on angle $\delta$ and $\varphi$ (see Fig. 3).

It is possible to rewrite the $d, q$-axis currents by imposing $\beta=(\delta-\varphi)$. Thus, the currents are $I_{d}=-I_{s} \cdot \sin (\beta)$ and $I_{q}=I_{s} \cdot \cos (\beta)$. If one will choose the $q$ axis as phase origin, in Fig. 2, the electric motor will operate to unity power factor $(\cos \varphi=1)$ if $\beta=\delta$. 
The purpose of this subsection is to introduce the control modeling of a PMSM and the controllability of the motor at unity power factor.

First of all, the motor model will be presented. After a short review of the vector control technique, the results of the PMSM control are presented.

From the PMSM equivalent circuit (Fig. 4), one can obtain the machine's mathematical model. The model takes into account the iron loss. The voltage equations, as a matrix, are:

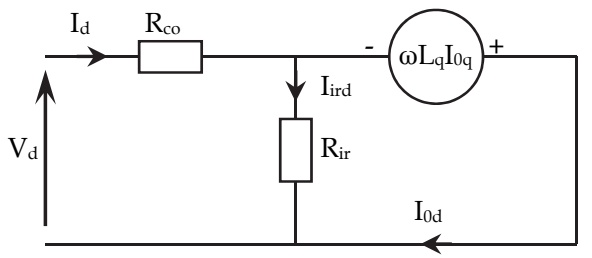

(a)

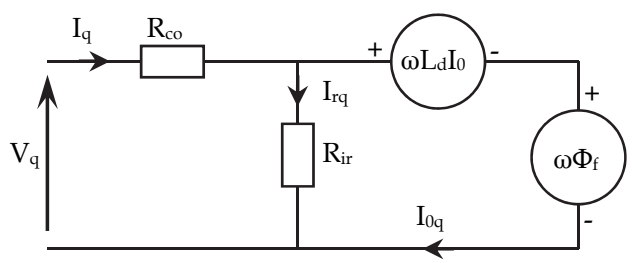

(b)

Fig. 4. The $d(\mathrm{a})$ and $q(\mathrm{~b})$ axis equivalent circuits.

$$
\left[\begin{array}{l}
\mathrm{V}_{\mathrm{d}} \\
\mathrm{V}_{\mathrm{q}}
\end{array}\right]=\mathrm{R}_{\mathrm{ph}} \cdot\left[\begin{array}{l}
\mathrm{I}_{\mathrm{d}} \\
\mathrm{I}_{\mathrm{q}}
\end{array}\right]+\left(1+\frac{\mathrm{R}_{\mathrm{ph}}}{\mathrm{R}_{\mathrm{ir}}}\right) \cdot\left[\begin{array}{cc}
0 & -\omega \cdot \mathrm{L}_{\mathrm{q}} \\
\omega \cdot \mathrm{L}_{\mathrm{d}} & 0
\end{array}\right] \cdot\left[\begin{array}{c}
\mathrm{I}_{0 \mathrm{~d}} \\
\mathrm{I}_{0 \mathrm{q}}
\end{array}\right]+\left[\begin{array}{c}
0 \\
\omega \cdot \lambda_{\mathrm{f}}
\end{array}\right]
$$

where: $V_{d, q}, L_{d, q}$ are the $d-q$ axis voltages and inductances, respectively; $\lambda_{f}$ represents the excitation flux produced by the PMs; $\mathrm{R}_{\mathrm{ir}}$, is the resistance corresponding to the iron loss.

The phase voltage and total torque equations are:

$$
\begin{gathered}
\mathrm{V}^{2}=\left(\omega \cdot \lambda_{\mathrm{f}}+\omega \cdot \mathrm{L}_{\mathrm{d}} \cdot \mathrm{I}_{0 \mathrm{~d}}+\mathrm{R}_{\mathrm{ph}} \cdot \mathrm{I}_{\mathrm{q}}\right)^{2}+\left(-\omega \cdot \mathrm{L}_{\mathrm{q}} \cdot \mathrm{I}_{0 \mathrm{q}}+\mathrm{R}_{\mathrm{ph}} \cdot \mathrm{I}_{\mathrm{d}}\right)^{2} \\
\mathrm{~T}=\mathrm{p} \cdot\left[\lambda_{\mathrm{f}} \cdot \mathrm{I}_{0 \mathrm{q}}+\left(\mathrm{L}_{\mathrm{d}}-\mathrm{L}_{\mathrm{q}}\right) \cdot \mathrm{I}_{0 \mathrm{~d}} \cdot \mathrm{I}_{0 \mathrm{q}}\right]
\end{gathered}
$$

with $\mathrm{I}_{0 \mathrm{~d}}=\mathrm{I}_{\mathrm{d}}-\mathrm{I}_{\text {ird }}$ and $\mathrm{I}_{0 \mathrm{q}}=\mathrm{I}_{\mathrm{q}}-\mathrm{I}_{\mathrm{irq}}$; representing the $\mathrm{d}$, $\mathrm{q}$ axis equivalent currents.

The copper and iron losses are:

$$
\begin{gathered}
P_{p h}=R_{p h} \cdot\left(I_{d}^{2}+I_{q}^{2}\right) \\
P_{\text {ir }}=R_{\text {ir }} \cdot\left(I_{\text {ird }}^{2}+I_{\text {irq }}^{2}\right)=\frac{\left(\omega \cdot L_{q} \cdot I_{0 q}\right)^{2}+\left(\omega \cdot \lambda_{\mathrm{f}}+\omega \cdot L_{d} \cdot I_{0 d}\right)}{R_{\text {ir }}}
\end{gathered}
$$

The motor speed equation is:

$$
\Omega_{\mathrm{s}}=\frac{\mathrm{V}^{2}}{\mathrm{p} \cdot \sqrt{\left(\lambda_{\mathrm{f}}-\mathrm{L}_{\mathrm{d}} \cdot \mathrm{I}_{\mathrm{d}}\right)^{2}+\left(\mathrm{L}_{\mathrm{q}} \cdot \mathrm{I}_{\mathrm{q}}\right)^{2}}}
$$


Vector-controlled drives were introduced about 30 years ago (as was stated in Buja \& Kazmierkowski, 2004) and they have achieved a high degree of maturity, being very popular in a wide range of applications in our days. It is an important feature of various types of vector controlled drives that they allow dynamic performance of AC drives to match or sometimes even to surpass that of the DC drive. At the present, the main trend is to use sensorless vector drives, where the speed and position information is obtained by monitoring input voltages or currents.

The vector control (VC) consists in controlling the spatial orientation of the electromagnetic field and has led to the name of field orientation. The FOC usually refers to controllers which maintain a $90^{\circ}$ electrical angle between the rotor $\mathrm{d}$-axis and the stator field components. Thus, with a FOC strategy, the field and armature flux are held orthogonal; moreover, the armature flux does not affect the field flux and the motor torque responds immediately to a change in the armature flux (or armature current). Hence, the AC motor behaves like a DC one.

A basic scheme of the FOC technique was used for the PMSM control. Having a speed and direct axis current as references and using PI controllers, one can obtain the needed stator voltage components for the motor supply. The employed simplified FOC scheme for our simulations is given in Fig. 5.

Direct torque control (DTC) technique was introduced about 20 years ago (as was stated in Bae et al., 2003). The principle of DTC is to directly select voltage vectors according to the difference between the reference and the actual value of the torque and the flux linkage. Thus, the torque and flux errors are compared in hysteresis comparators. Depending on the comparators a voltage vector is selected from the well known switching table of the DTC technique.

In general, compared to the conventional FOC scheme, the DTC is inherently a sensorless control method; it has a simple and robust control structure (however, the performances of DTC strongly depends on the quality of the estimation of the actual stator flux and torque).

The implemented simplified DTC scheme is given in Fig. 6. Here, from the current and speed controllers, it is possible to get the flux and torque references The reference values are compared with the measured ones. From the obtained errors, one can get the voltage vector selection in order to assure the PMSM supply after an $a b c=>d q$ transformation.

In contrast to induction motors the initial value of the stator flux in PMSM is not zero and depends on the rotor position. In motion-sensorless PMSM drives the initial position of the rotor is unknown and this often causes initial backward rotation and problems of synchronization. Otherwise, the DTC system possesses good dynamic performances, but in steady state regime the torque-current-flux ripples present high levels.

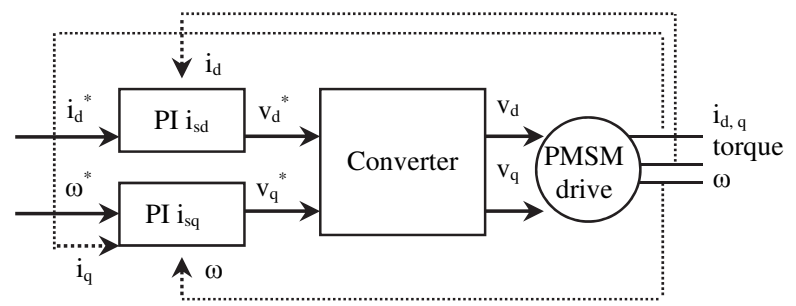

Fig. 5. Simplified basic scheme of the implemented FOC technique. 


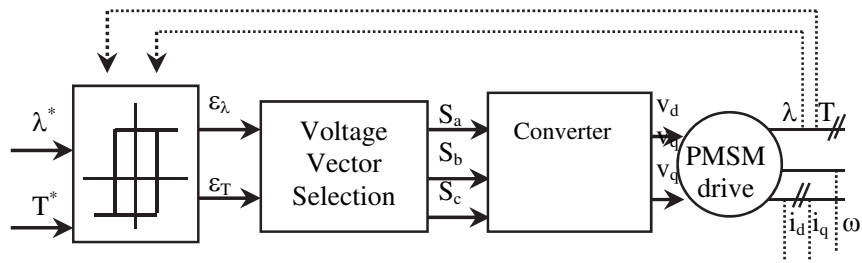

Fig. 6. Simplified basic scheme of the implemented DTC technique.

Both techniques can be used for controlling the PMSM at unity power factor. Here, the FOC was employed.

The internal angle of the PMSM can be expressed function of $d, q$ axis voltages: $\tan \delta=-V_{d} / V_{q}$. Then, in stationary regime (derivate terms are suppressed), one will get:

$$
\tan \delta=\frac{R_{p h} \cdot I_{s} \cdot \sin \beta+\omega \cdot L_{q} \cdot I_{s} \cdot \cos \beta}{R_{p h} \cdot I_{p h} \cos \beta-\omega \cdot L_{d} \cdot I_{s} \cdot \sin \beta+\omega \cdot \Psi_{m}}
$$

Neglecting the phase resistance, the internal angle tangent becomes:

$$
\tan \delta=\frac{\omega \cdot \mathrm{L}_{\mathrm{q}} \cdot \mathrm{I}_{\mathrm{s}} \cdot \cos \beta}{-\omega \cdot \mathrm{L}_{\mathrm{d}} \cdot \mathrm{I}_{\mathrm{s}} \cdot \sin \beta+\omega \cdot \Psi_{\mathrm{m}}}
$$

For unity power factor, $\beta$ equals $\delta$ and the following expression is obtained:

$$
\frac{\sin \beta}{\cos \beta}=\frac{\omega \cdot L_{q} \cdot I_{s} \cdot \cos \beta}{-\omega \cdot L_{d} \cdot I_{s} \cdot \sin \beta+\omega \cdot \Psi_{m}}
$$

One will get, after calculation, a second degree equation which solution is:

$$
\sin \beta=\frac{1 \pm \sqrt{1-4 \cdot \frac{\mathrm{L}_{\mathrm{d}} \cdot \mathrm{L}_{\mathrm{q}} \cdot \mathrm{I}_{\mathrm{s}}^{2}}{\Psi_{\mathrm{d}}} \cdot\left(1-\frac{\mathrm{L}_{\mathrm{q}}}{\mathrm{L}_{\mathrm{d}}}\right)}}{2 \cdot \frac{\mathrm{L}_{\mathrm{d}} \cdot \mathrm{I}_{\mathrm{s}}}{\Psi_{\mathrm{m}}} \cdot\left(1-\frac{\mathrm{L}_{\mathrm{q}}}{\mathrm{L}_{\mathrm{d}}}\right)}
$$

In this way, the $\mathrm{d}$, q currents will be computed for unity power factor.

The simulations results are presented in Fig. 7-Fig. 8. After 0.5 seconds, a reference speed is imposed. The measured speed follows the reference one, and in a very short time it reaches the desired value. This acceleration is accompanied by a current supply, from the electric source. Since the motor is of orthogonal type (a Park transformation was used to transform the 3 phase equation system in a 2 phase one), we will exploit the direct and quadrature axis currents to produce de torque and to evaluate the active and reactive power. To maximize the torque, the $I_{d}$ should be imposed to zero. Thus, the $I_{q}$ is the image of the axis torque.

The active and reactive powers are computed based on direct and quadrature currents and voltages, respectively. From those values, one can compute the energetic performances of the designed PMSM, Fig. 8. For a load torque of $2.2 \mathrm{~N} \cdot \mathrm{m}$, the absorbed electric power (corresponding to the active power $\mathrm{P}$ ) is of $379 \mathrm{~W}$, meaning that an efficiency of $92.3 \%$ is obtained through this vector control strategy. The reactive power is used for the computation of the power factor. 

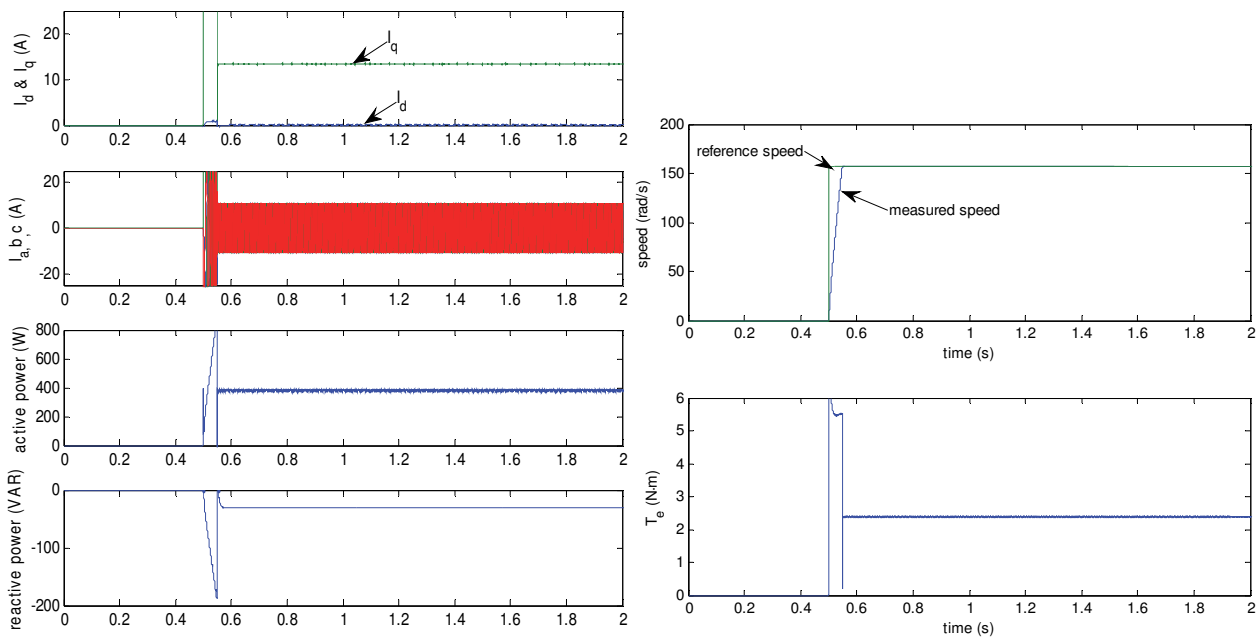

(a)

(b)

Fig. 7. PMSM simulation results: (a) electrical performances; (b) mechanical performances.
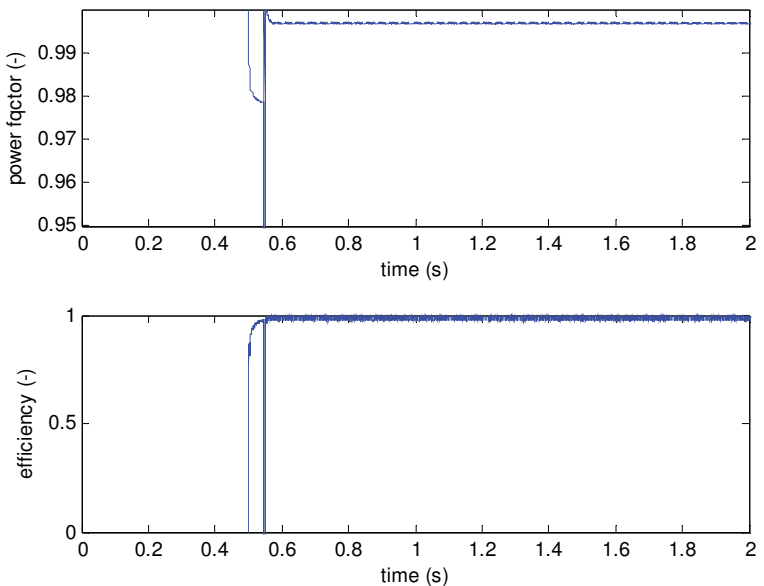

Fig. 8. PMSM simulation results: energetic performances.

Based on the obtained simulation results, it can be said that the analytical approach was validated. The unity power-factor control strategy has been successfully employed since the simulated results show a power factor over $99 \%$ !

\section{Numerical validation of the designed PMSM}

In order to prove the electromagnetic design validity, it has been employed a numerical computation based on finite element method (FEM). This analysis has been carried out by using Flux2D. The FEM analysis of PMSM in motor operation regime is employed at rated speed $\left(1500 \mathrm{~min}^{-1}\right)$, while the stator is fed with three currents delayed in time by $120^{\circ}$. 
The saturation level can be observed in Fig. 9. In Fig. 10 have been plotted the air-gap flux density, the 3-phase sinusoidal currents, axis torque and iron loss. It can be observed that the air-gap flux-density value is very close to the one obtained from analytical approach, $0.826 \mathrm{~T}$. On the other hand, the rated torque is obtained based on rated current. Also, thanks to the proper winding-slots-poles configurations, the torque ripples are significantly reduced. In fact, the ratio of torque ripple is of $0.8 \%$ (maximum at $2.222 \mathrm{~N} \cdot \mathrm{m}$ and minimum at $2.204 \mathrm{~N} \cdot \mathrm{m}$ )! For the computed iron loss (average value) a supplementary explanation is needed.

It has been observed that from analytical approach the iron loss is of $34.42 \mathrm{~W}$. From FEM analysis, the average value of iron loss is $27.573 \mathrm{~W}$, meaning that an improved efficiency is obtained. This difference can be explained regarding Fig. 9, where the flux density is depicted in the machine's active part. Here, the flux density varies significantly in the stator iron, while in the analytical approach a fixed maximum flux density was used. Since the FEM analysis has more credit, it can be said that $2 \%$ improved efficiency is obtained!

\section{Optimization of the designed PMSM}

After the design process and numerical validation, the optimization approach of the studied electrical machine will be presented. Since we want to obtain a specific power for the PMSM, we could say that our optimization objective will be to reduce the volume of the machine (consequently the mass of the active parts of the machine), while the output power is maintained constant (or very close to the desired value). Thus, the objective function is to minimize the mass of the active parts of the PMSM. This mass, called $m_{\text {tot }}$ is defined by the mathematical expression:

$$
\mathrm{m}_{\mathrm{tot}}=\mathrm{m}_{\text {copper }}+\mathrm{m}_{\mathrm{rs}}+\mathrm{m}_{\mathrm{ss}}+\mathrm{m}_{\mathrm{pm}}
$$

where $\mathrm{m}_{\text {copper }}$ refers to the mass of the winding copper, $\mathrm{m}_{\mathrm{rs}}$ is the mass of the rotor steel, $\mathrm{m}_{\mathrm{ss}}$ is the mass of the stator steel and $\mathrm{m}_{\mathrm{pm}}$ is the mass of the permanent magnet.

\subsection{The optimization method}

The optimization of studied electrical machine is based on gradient algorithm, (Tutelea \& Boldea, 2007). The main steps in the optimization algorithm are:

Step 1. Choose the optimization variables (which will be modified in the process; starting value and boundaries of the optimization variables are imposed).

Step 2. Impose special limitations of other variables which can be altered during process.

Step 3. Define the objective function.

Step 4. Set initial and final value of global increment. The objective values will be initially modified with larger increment, which will be further decreased in order to refine the search space.

Step 5. Compute geometrical dimensions, the electromagnetic parameters and the characteristics (given in section 2.c), and evaluate the objective function.

Step 6. Make a movement in the solution space and recompute the objective function and its gradient. Use partial derivative to find the worse and the track points.

Step 7. Move to the better solution, while the objective function is decreasing.

Step 8. Reduce the variation step and repeat the previous steps. The algorithm stops when the research movement cannot find better solution, even with smallest variation step. The found value represents a local minimum; a different value can be found by changing the initial starting point. 


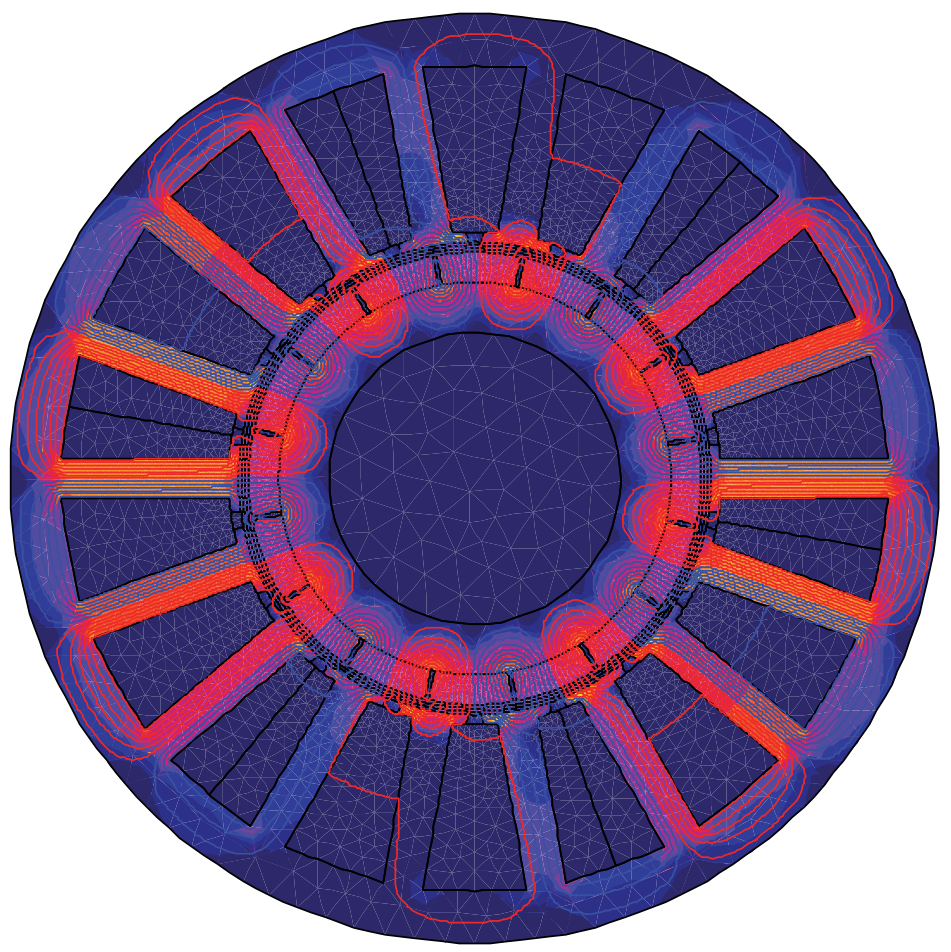

Color Shade Results

Quantity: IFlux densityl Tesla

Time (s.) : 111.109999E-6 Pos (deg): 10.75

Scale / Color

27.0013E-9 / 139.34316E-3

139.34316E-3 / 278.68629E-3

278.68629E-3 / 418.02937E-3

418.02937E-3 / 557.37251E-3

557.37251E-3 / 696.71565E-3

696.71565E-3 / 836.0588E-3

836.0588E-3 / 975.40188E-3

975.40188E-3 / 1.11475

1.11475 / 1.25409

1.25409 / 1.39343

1.39343 / 1.53277

1.53277 / 1.67212

1.67212 / 1.81146

1.81146 / 1.9508

1.9508 / 2.09015

2.09015 / 2.22949

Fig. 9. Flux-density and field lines for studied PMSM. 

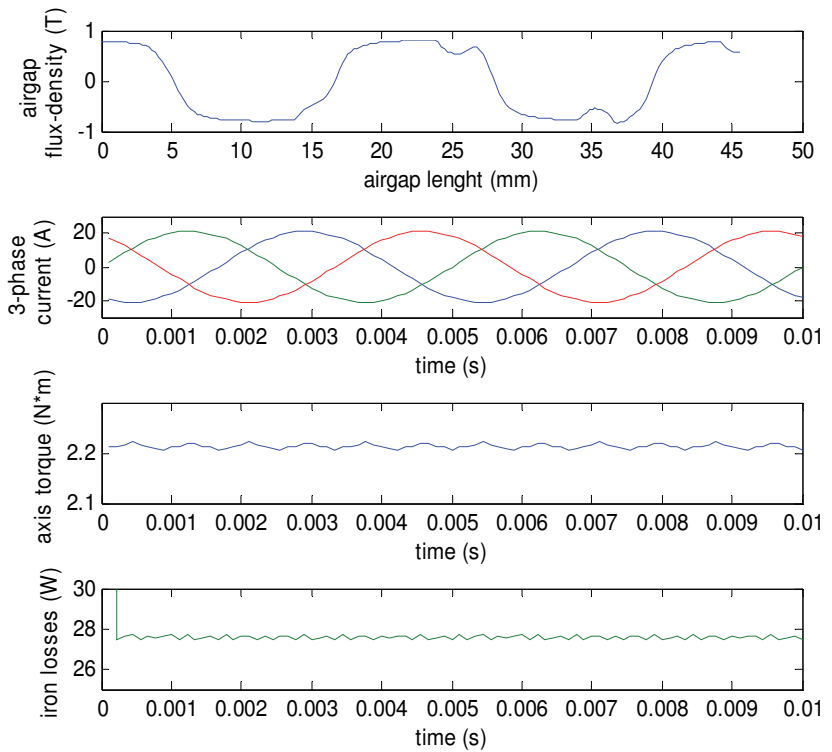

Fig. 10. FEM results of PMSM in motor regime.

The goal of the optimization process is to maximize the power density (power/mass ratio) this is our objective function. The parameters to be varied, in the optimization process, are: the length of the machine, the air-gap length, the PM length (on the magnetization direction), the inner stator diameter, the stator slot's height, the tooth width, the stator yoke height and isthmus height. The initial values and the boundaries are given in Table 4.

\begin{tabular}{|l|c|c|}
\hline \multicolumn{1}{|c|}{ parameter } & Initial value & Boundaries \\
\hline inner stator diameter $(\mathrm{mm})$ & 59 & {$[30 \ldots 80]$} \\
\hline slot height $(\mathrm{mm})$ & 13.4 & {$[8 \ldots 18]$} \\
\hline isthmus height $(\mathrm{mm})$ & 1.5 & {$[0.7 \ldots 3]$} \\
\hline height of the stator yoke & 5 & {$[3 \ldots 9]$} \\
\hline width of stator tooth $(\mathrm{mm})$ & 4 & {$[3 \ldots 8]$} \\
\hline air-gap length $(\mathrm{mm})$ & 1 & {$[0.5 \ldots 1.5]$} \\
\hline height of the PM on magnetization direction $(\mathrm{mm})$ & 3 & {$[2 \ldots 6]$} \\
\hline length of the machine $(\mathrm{mm})$ & 43.5 & {$[20 \ldots 6]$} \\
\hline
\end{tabular}

Table 4. Optimization variables: initial values and boundaries.

Supplementary constraints were considered for the mechanical outputs (torque and power) and electrical (supplied current) characteristics, see Table 5.

\begin{tabular}{|l|c|}
\hline \multicolumn{1}{|c|}{ parameter } & Bouderies \\
\hline Axis torque $(\mathrm{N} \cdot \mathrm{m})$ & {$[2.1 \ldots 2.3]$} \\
\hline Output power $(\mathrm{W})$ & {$[340 \ldots 360]$} \\
\hline Supplied current $(\mathrm{A})$ & {$[13 \ldots 18]$} \\
\hline
\end{tabular}

Table 5. Optimization variables: supplementary constraints. 


\subsection{Obtained results}

The optimization procedure was lunched. The iterative process has reached its optimum after 672 steps, the simulation time being 5.58 seconds on an Intel Core 2 of $2 \mathrm{Ghz}$ processor, $2 \mathrm{~Gb}$ RAM.

In Fig. 11 have been plotted the current source, the output power and axis torque, to prove that the supplementary constraints were satisfied. The current reaches its upper limit after 672 steps, thus the optimization process is stopped. It is true, the copper loss will increase a little bit, but will not affect drastically the efficiency.

Next, the evolution of the geometric and energetic parameters is plotted in Fig. 12. Not all the geometric parameters are shown. Here, only the stator tooth width, the PM's height and stator yoke's height are presented as a sample. It can be seen that some parameters are maintained constant, while others are varied. The gradient type optimization algorithms are sometimes limited and they do not exploit every possible solution (meaning that a local optimum was reached, and the algorithm cannot exit from this local optimum). In order to see other possible geometrical solutions, the user needs to change the starting values; thus, new solution could appear.

It is obvious that, if the current source will increase, the copper loss will increase too. This is a normal behavior, since we want to keep the same number of turns per phase, and not to increase the copper volume. On the other hand, since the geometry volume was reduced, the iron loss is decreased too. Thus, there is compensation on the efficiency.

Practically, the efficiency of the machine has, globally, increased with $1.6 \%$. The power factor has kept the starting value. Thus, with a proper control, this parameter can be optimized.

Finally, the objective function evolution, and the power density ratio are plotted in Fig. 13. If the initial mass of the active parts of the machine was $2.6 \mathrm{~kg}$, the optimized PMS has only $1.93 \mathrm{~kg}$, meaning a mass gain of $28 \%$.

The resume of the optimized results of the PMSM are given in Table 6.

\begin{tabular}{|l|c|c|}
\hline \multicolumn{1}{|c|}{ parameter } & PMSM-RF & Gain (\%) \\
\hline Rated current (A) & 18 & -7.6 \\
\hline Losses $(\mathrm{W})$ & 67.4 & +5.6 \\
\hline Power factor $(\%)$ & 59.8 & -1.8 \\
\hline Efficiency $(\%)$ & 84.4 & +1.6 \\
\hline Active part costs $(€)$ & 22.79 & +16.1 \\
\hline Active part weight $(\mathrm{kg})$ & 1.93 & +28.3 \\
\hline Power/weight $(\mathrm{W} / \mathrm{kg})$ & 194.3 & +33.1 \\
\hline
\end{tabular}

Table 6. Main optimization results, at rated operating point, of the PMSM.

(In order to validate the obtained optimization results, the author has introduced again the modified parameters into the FEM software to re-compute the performances of the designed machine. The optimization results have been confirmed by the FEM analysis, like the results presented in Section 3.) 

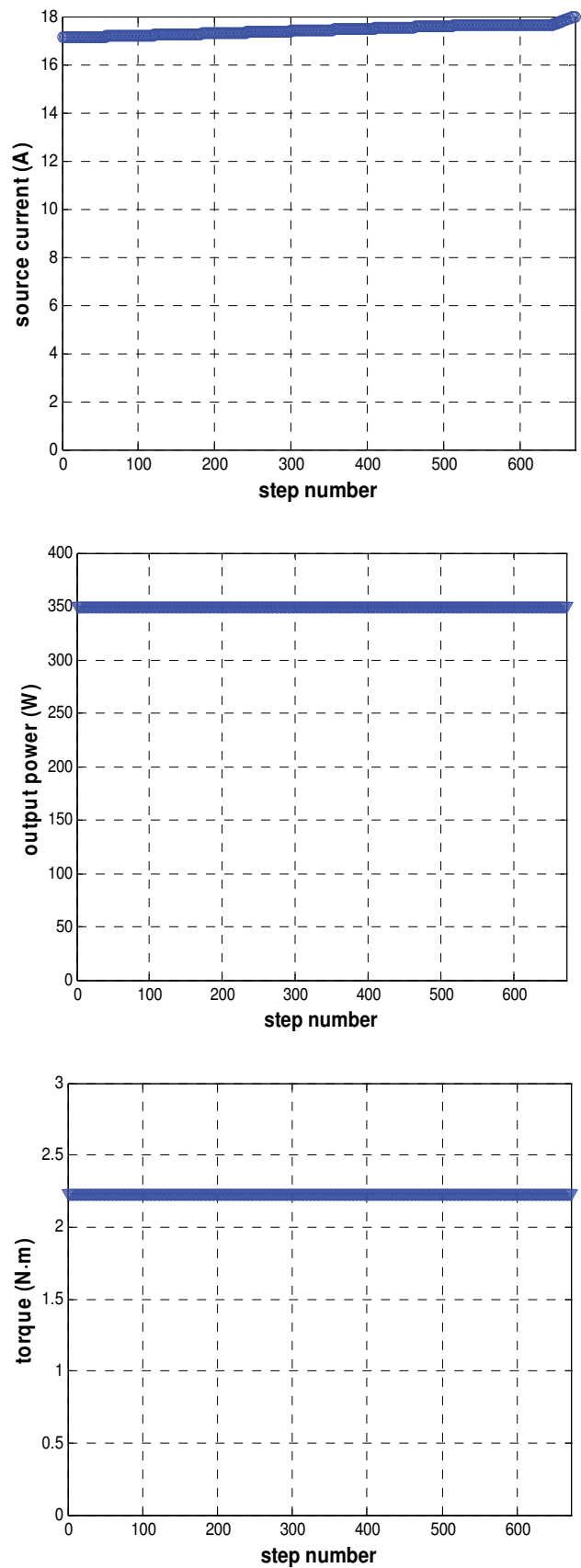

Fig. 11. Optimization results of PMSM: source current and mechanical performances constraints. 

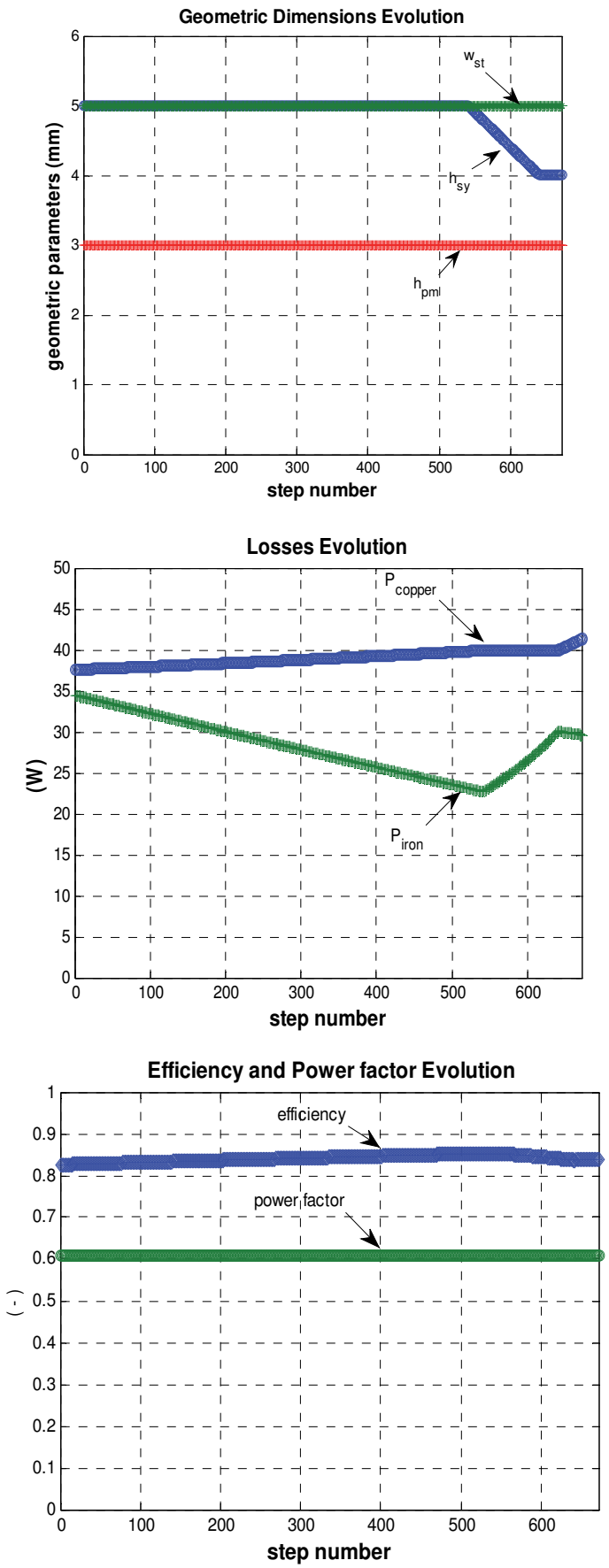

Fig. 12. Optimization results of PMSM: evolution of geometrical and energetic parameters. 

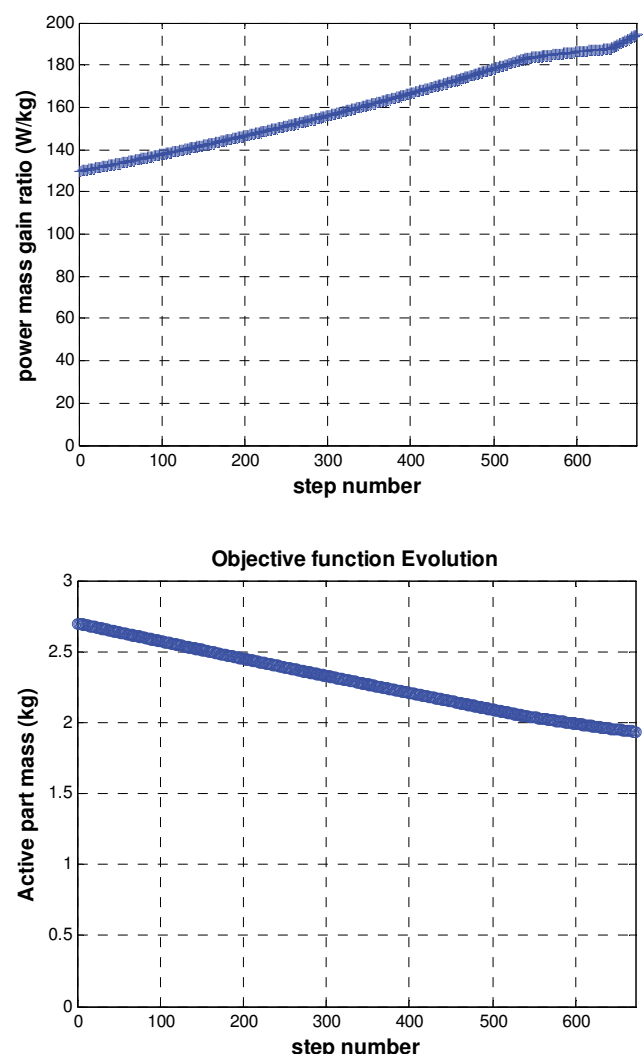

Fig. 13.Optimization results of PMSM: power density and mass improvement.

\section{Conclusions}

The paper presents the main steps to be followed in the design process of a permanent magnet synchronous machine used for light electric vehicles. Even if the analytical approach is not completely detailed, it contains the major elements which need to be discussed. Detailed equations are presented for the calculation of the desired output characteristics, based on certain mechanical performances. Thus, for a specific load and taking into account the vehicle's weight and the road profile, it is possible to get the needed output power which will be capable to run the vehicle.

Usually, the traction of light electric vehicles is employed with dc motors. The disadvantage of such a motor is related to its poor efficiency and power density. The permanent magnet synchronous machine (PMSM) has the best power/mass ratio, and very high efficiency. Nevertheless, two problems need to be solved for the PMSM: one is related to the poor power factor and the other one to the torque ripples. The first problem is solved with a proper vector control technique, while the second issue is solved with a proper winding configuration. A fractioned type winding configuration was used for the PMSM, and a very smooth torque was obtained: the torque ripples are of $0.8 \%$. 
The design of the PMSM is completed with the optimization of the motor, based on gradient type algorithm. The objective function of the problem is the minimization of the machine's active parts mass, while the output power is kept practically constant. After the optimization process, the mass of the PMSM was reduced with $28 \%$, at the same energetic performances (efficiency and power factor). This mass decrease involves also an investment decrease of $16 \%$.

\section{Acknowledgments}

This research work was supported by CNCSIS-UEFISCDI, project type TE-250, contract number 32/28-07-2010.

\section{References}

Bae, B.H.; Sul, S.K., Kwon, J.H. \& Shin, J.S. (2003). Implementation of sensorless vector control for super high speed PMSM of turbo-compressor. IEEE Transactions on Industry Applications, Vol.39, No.3, (May-June 2003), pp.811-818, ISSN: 00939994.

Buja, G.S. \& Kazmierkowski, P. (2004). Direct torque control of PWM inverter fed AC motor - A survey. IEEE Transactions on Industrial Electronics, Vol.51, No.4, (August 2004), pp.744-757, ISSN: 0278-0046.

Ceraolo, M., Caleo, A., Campozella, P. \& Marcacci, M. (2006). A parallel-hybrid drive-train for propulsion of a small scooter. IEEE Transactions on Power Electronics, Vol.21, No.3, (March 2006), pp.768-778, ISSN: 0885-8993.

Chenh-Hu C. \& Ming-Yang, C. (2007). Implementation of a highly reliable hybrid electric scooter drive. IEEE Transactions on Industrial Electronics, Vol.54, No.5, (March 2007), pp.2462-2473, ISSN: 0278-0046.

Ehsani, M., Gao, Y., Gay, S.E. \& Emadi, A. (2005). Hybrid Electric, and Fuel Cell Vehicles: Fundamentals, Theory, and Design. CRC Press.

Fitzgerald, A.E., et al. (2003). Electric Machinery - 6 th edition, McGraw-Hill.

Fuhs, A.E. (2009). Hybrid vehicle and the future of personal transportation. CRC Press.

Huang, A.S., Luo, J., Leonardi, F. \& Lipo, T.A. (1998). A general approach to sizing power density equation for comparison of electrical machines. IEEE Trans. on Industry Applications, Vol.34, No.1, (January 1998), pp.92-97, ISSN: 0093-9994.

Naidu, M., Nehl, T.W., Gopalakrishnan, S. \& Würth, L. (2005). A semi-integrated, sensorless PM brushless drive for a 42-V automotive HVAC compressor. IEEE Industry Application Magazine, July-August 2005, pp.20-28, ISSN: 1077-2618.

Pyrhonen, J., Jokinen, T. \& Hrabovcova, V. (2008). Design of Rotating Electrical Machines, John Wiley \& Sons.

Tutelea, L. \& Boldea, I. (2007). Optimal design of residential brushless d.c. permanent magnet motors with FEM validation, International AGEAN Conference on Electrical Machines and Power Electronics, Antalya, Turkey, 2007, pp.435-439.

Vogel, C. (2009). Build Your Own Electric Motorcycle, McGraw-Hill Companies. 


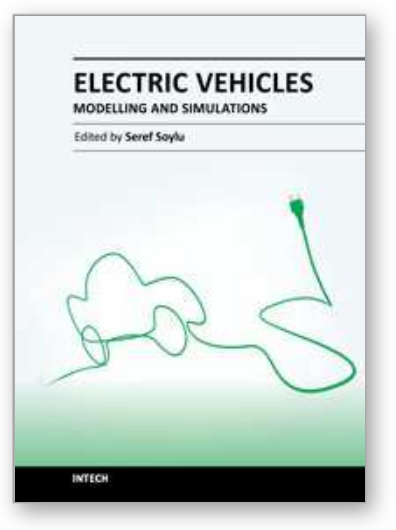

\author{
Electric Vehicles - Modelling and Simulations \\ Edited by Dr. Seref Soylu
}

ISBN 978-953-307-477-1

Hard cover, 466 pages

Publisher InTech

Published online 12, September, 2011

Published in print edition September, 2011

In this book, modeling and simulation of electric vehicles and their components have been emphasized chapter by chapter with valuable contribution of many researchers who work on both technical and regulatory sides of the field. Mathematical models for electrical vehicles and their components were introduced and merged together to make this book a guide for industry, academia and policy makers.

\title{
How to reference
}

In order to correctly reference this scholarly work, feel free to copy and paste the following:

Daniel Fodorean (2011). Global Design and Optimization of a Permanent Magnet Synchronous Machine Used for Light Electric Vehicle, Electric Vehicles - Modelling and Simulations, Dr. Seref Soylu (Ed.), ISBN: 978-953307-477-1, InTech, Available from: http://www.intechopen.com/books/electric-vehicles-modelling-andsimulations/global-design-and-optimization-of-a-permanent-magnet-synchronous-machine-used-for-lightelectric-veh

\section{INTECH}

open science | open minds

\author{
InTech Europe \\ University Campus STeP Ri \\ Slavka Krautzeka 83/A \\ 51000 Rijeka, Croatia \\ Phone: +385 (51) 770447 \\ Fax: +385 (51) 686166 \\ www.intechopen.com
}

\author{
InTech China \\ Unit 405, Office Block, Hotel Equatorial Shanghai \\ No.65, Yan An Road (West), Shanghai, 200040, China \\ 中国上海市延安西路65号上海国际贵都大饭店办公楼 405 单元 \\ Phone: +86-21-62489820 \\ Fax: +86-21-62489821
}


(C) 2011 The Author(s). Licensee IntechOpen. This chapter is distributed under the terms of the Creative Commons Attribution-NonCommercialShareAlike-3.0 License, which permits use, distribution and reproduction for non-commercial purposes, provided the original is properly cited and derivative works building on this content are distributed under the same license. 